\title{
A new species of deepwater flathead, Bembras adenensis (Scorpaeniformes: Bembridae) from the western Indian Ocean
}

\author{
Hisashi Imamura $^{1} \&$ Leslie W. Knapp ${ }^{2}$ \\ ${ }^{1}$ Hachinohe Branch, Tohoku National Fisheries Research Institute, 25-259 Same, Hachinohe, Aomori 031, Japan \\ ${ }^{2}$ Department of Vertebrate Zoology, National Museum of Natural History, Smithsonian Institution, \\ Washington D.C 20560,USA (e-mail: knapp.leslie@Simnh.si.edu)
}

(Received 3 July 1996; in received from 1 November 1996; accepted 2 November 1996)

Ichthyological

Research

(C) The Ichthyological Society of Japan J 997
Imamura, H. and L. W Knapp. 1997. A new species of deepwater flathead, Bembras adenensis (Scorpaeniformes: Bembridae) from the western Indian Ocean. Ichthyo1. Res., 44 (1): 9-14.

Abstract A new bembrid, Bembras adenensis, is described on the basis of specimens collected from the Gulf of Aden, western Indian Ocean. This species is easily distinguished from $B$. japonica, the only known congener of the genus, by the following combination of characters: larger orbital diameter, longer head length, pectoral-fin with a small black blotch near tip of upper rays, 3 gill rakers on upper gill arch, 19 pectoral-fin rays, and 15 anal-fin rays (vs. smaller orbital diameter, shorter head length, pectoral-fin with several small spots forming irregular bands, 2 gill rakers on upper gill arch, usually 17 pectoral-fin rays, and

14 anal-fin rays in B. japonica).

Key words. - Bembras adenensis sp. nov.; Gulf of Aden; B. japonica.
The bembrid (sensu Nelson, 1994) genus Bembras, established by Cuvier (1829) with $B$. japonicus as the type species, is characterized by head only slightly depressed and armed with spines, body long and slender, upper jaw projecting beyond lower with mouth closed, and anal fin without spines. Since Cuvier's original description, B. japonica has been reported previously from northern Japan to the South China Sea, the Gulf of Aden, southern Indonesia, and Australia (Jordan and Richardson, 1908; Matsubara, 1955; Matsubara and Ochiai, 1955; Chu et al., 1962; Knapp, 1979; Gloerfelt-Tarp and Kailola, 1984; Ochiai, 1984; Sainsbury et al., 1985; Shao and Chen, 1987; Paxton et al., 1989; Nakabo, 1993). Knapp (1979) described Bembras japonicus based on four specimens collected from the Gulf of Aden, by the R/V Meteor during the Meteor expedition to the western Indian Ocean in December 1964. Reexamination of these specimens deposited in Zoologisches Institut und Zoologis- ches Museum $(\mathrm{ZMH})$ revealed that they represent an undescribed species and that they differ from B. japonica in having a larger orbital diameter, a longer head, a pectoral-fin with a small black blotch near tip of upper rays, 3 gill rakers on upper gill arch, 19 pectoral-fin rays, and 15 anal-fin rays. The new species of Bembras that we describe in detail here is based on these specimens.

\section{Materials and Methods}

Counts and measurements were made according to Hubbs and Lagler (1958) except body depth and width were measured at origin of the second dorsal fin. Specimen lengths were expressed as standard length (SL). Measurements were made with calipers to the nearest 0.1 $\mathrm{mm}$. Vertebral counts were taken from radiographs. Names of head spines follow Knapp (1986). In 


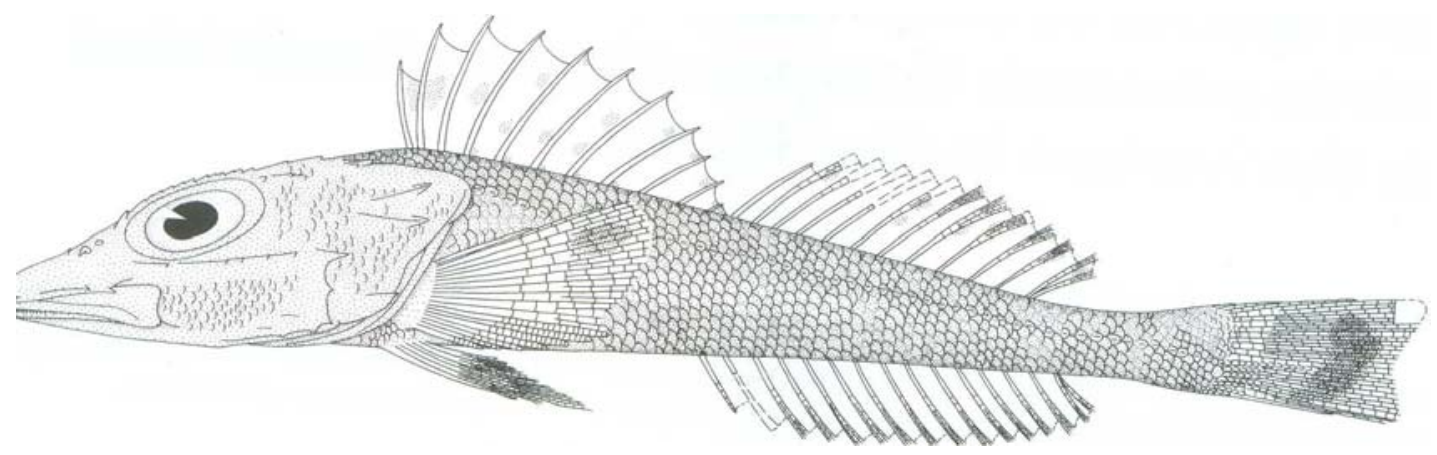

Fig. 1. Lateral view of Bembras adenensis sr. nov., holotype, ZMH 5291, 154mm

SL, Gulf of Aden, western Indian Ocean.

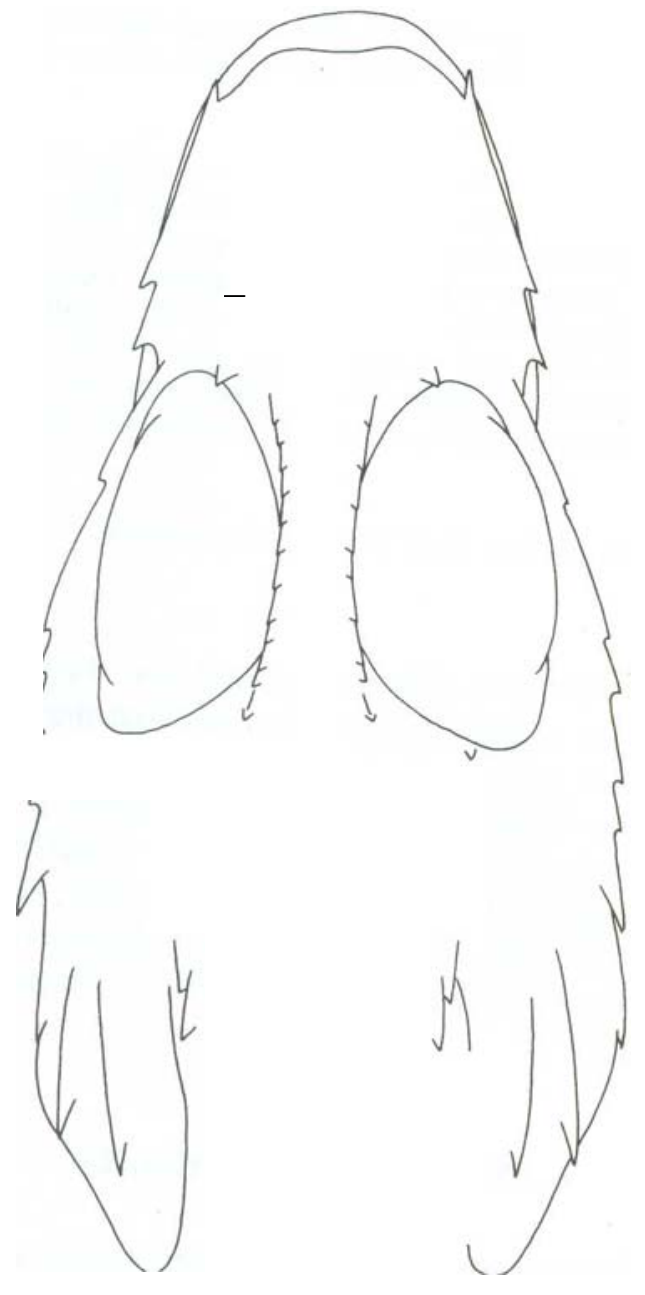

$10 \mathrm{~mm}$

Fig. 2. Dorsal view of head of Bembras adenensis sr. nov., holotype, ZMH 5291, $154 \mathrm{~mm}$ SL, Gulf of Aden, western Indian Ocean.

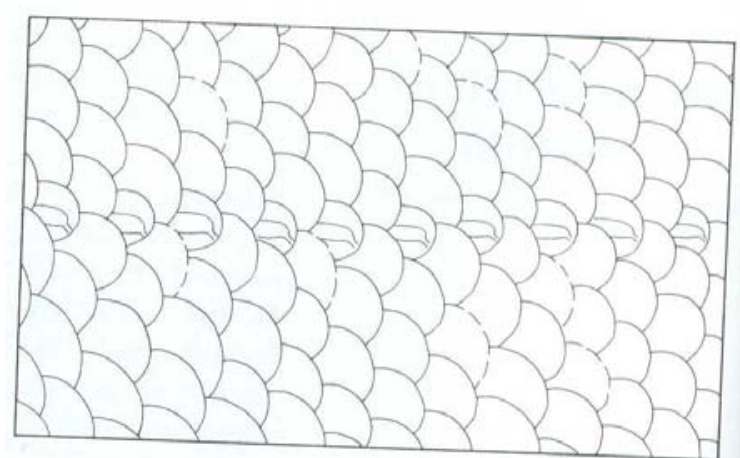

$5 \mathrm{~mm}$

Fig. 3. Lateral view of scales on midbody (below 9th dorsal spine to 3rd soft ray) on left side of Rembras adenensis sr. nov., holotype, ZMH 5291 $154 \mathrm{~mm}$ SL, Gulf of Aden, western Indian Ocean.

stitutional abbreviations follow Leviton et, (1985).

\section{Bembras adenensis sp. novo}

(Figs. 1-3)

Bembras japonicus (non Cuvier, 1829): Knapp, 1979:

fig. 526 (Gulf of Aden, western Indian Ocean).

Holotype. ZMH 5291, $154 \mathrm{~mm}$ SL, Gulf of Aden, western Indian Ocean $\left(12^{\circ} 12^{\prime} \mathrm{N}, 43^{\circ} 36^{\prime} \mathrm{E}\right)$, trawled by $\mathrm{R} / \mathrm{V}$ Meteor, $225 \mathrm{~m}$ depth, ]4 Dec. 1964 (figured in Knapp, 1979).

Paratypes. ZMH 8810 (formerly ZMH 5291), 2 speci-mens, 137-139mm SL, collected with holotype; USNM 338873 (formerly ZMH 5291), 1 specimen, $152 \mathrm{~mm}$, SL, collected with holotype.

Diagnosis. A species of Bembras with large 
orbital diameter (30.4-32.5\% of head length [HL]) and head (38.4-42.0\% of SL), small black blotch near tip of upper rays of pectoral fin, and a high number of gill rakers on upper gill arch (3), pectoral-fin rays (19) and anal-fin rays (15).

Description. Data for the holotype are presented first, followed by paratype data in parentheses: dorsal-fin rays XI-I, 11 (XI-I, 11); analfin rays 15 (15); pectoral-fin rays 2 (upper, unbranched) +10 (middle, branched)+7 (lower, unbranched $)=19(2+9-10+7-8=19)$; pelvic-fin rays $\mathrm{I}, 5(\mathrm{I}, 5)$; branched caudal-fin rays 8 (upper) +6 (lower) $(8+6)$; vertebrae $10+17=27$ $(10+17=27)$; gill rakers $3+11=14(3+1011=13-$ $14)$; scales in lateral line 54, anterior 4 scales with a distinct spine (54-55, 5-6 with spine); scale rows slanting backward and downward above lateral line 54 (54-56). Proportions as \% SL: HL 40.8 (38.4-42.0); body depth 12.0 (12.013.4); body width 9.8 (8.8-10.4); predorsal length 37.1 (35.5-40.5); length of first dorsal-fin base 25.6 (23.5-25.6); length of second dorsalfin base 25.9 (24.9-26.1); length of analfin base 29.1 (28.8-30.0); length of caudal peduncle 13.6 (12.6-14.4); depth of caudal peduncle 5.3 (5.5$5.8)$; snout length 12.5 (12.1-12.5); orbital diameter 12.4 (11.8-13.2); upper-jaw length 15.1 (14.0-15.3); lower-jaw length 19.5 (18.5-19.9); interorbital width $2.3(2.2-2.4)$; pectoral-fin length 20.2 (20.8-21.5); pelvic-fin length 17.7 (17.7-18.8); caudal-fin length 19.0 (19.9-20.9); length of first spine of first dorsalfin 7.6 (7.78.8 ); length of second spine of first dorsal-fin 10.8 (11.5-11.7); length of first spine of second dorsal-fin 9.1 (9.6-9.9); length of first ray of second dorsal-fin-(12.5-12.8); length of first anal-fin ray 6.0 (5.6-6.2). Proportions as \% HL: snout length 30.7 (29.7-31.5); orbital diameter 30.4 (30.4-32.5); upper-jaw length 37.1 (34.837.9); lower-jaw length 47.9 (46.2-49.3); interorbital width 5.6 (5.5-6.4).

Body long and slender, depth 8.3 (7.5-8.3), width 10.2 (9.6-11.3) in SL; mostly covered with ctenoid scales, some cycloid scales on under surface. Head large, posterior margin opercle reaching beyond below to fourth spine of first dorsal fin, length 2.5 (2.4-2.6) in SL; posterior dorsal surface, opercle, postorbital and cheek regions scaly. Snout slender, as long as orbital diameter, 3.3 in HL (as long as, or slightly shorter than orbital diameter, 3.2-3.4 in HL). Iris lappet absent. Interorbit narrow, less than one fifth orbit diameter, 17.9 (15.7-18.1) in HL. Top and sides of head armed with spines (Figs. 1 and 2). Posttemporal with strong spine posteriorly, bearing small spine laterally. Opercle armed with two strong spines, with a distinct ridge lacking serrations. Preopercle armed with five spines, uppermost longest, all without supplementary spines. Subopercle with a distinct spine posteroventrally. Parietal ridge with one strong spine. Lateral surface of head with a suborbital ridge armed with five spines. Lachrymal with one forward and two backward spines. Weak nasal spine present. Preorbital spine absent. A preocular spine in front of eye. Supraorbital ridge with rough serration comprised of nine (right side) and twelve (left) spines. A spine present between posteriormost supraorbital and parietal spines on left side, but absent on left. Postocular spine present. Pterotic ridge armed with one (right side) and two (left) spines. Interopercular flap absent. Maxilla not reaching middle of eye, length 2.7 (2.6-2.9) in HL. Anterior tip of upper jaw slightly projecting beyond that of lower jaw when mouth closed. Small canine teeth in bands on jaws and palatine, in a Vsharped patch on prevomer. Body scales small, number of oblique scale rows slanting downward and forward above lateral line more than that of lateral line scales; number of oblique scale rows slanting downward and backward above it about equal to latter (Fig. 3). Each pored scales in lateral line with a exterior opening posteroventrally (Fig. 3). First dorsal-fin originating well behind posterior margin of opercle. First and second dorsal fins separated narrowly. Origin of pectoral-fin posterior to that of pelvic-fin. Pectoralfin rounded posteriorly, length $2.0(1.8-2.0)$ in HL. Pelvic fin short, not reaching to anus, its length 2.3 (2.2-2.3) in HL. Caudal fin slightly concave posteriorly, length 2.2 (1.9-2.1) in HL.

Color in ethanol. - According to Knapp (1979), dorsum light brown with a few small darker spots; both dorsal fins with a series of small brown spots; caudal fin with a broad submarginal black band; pectoral-fin with a small 


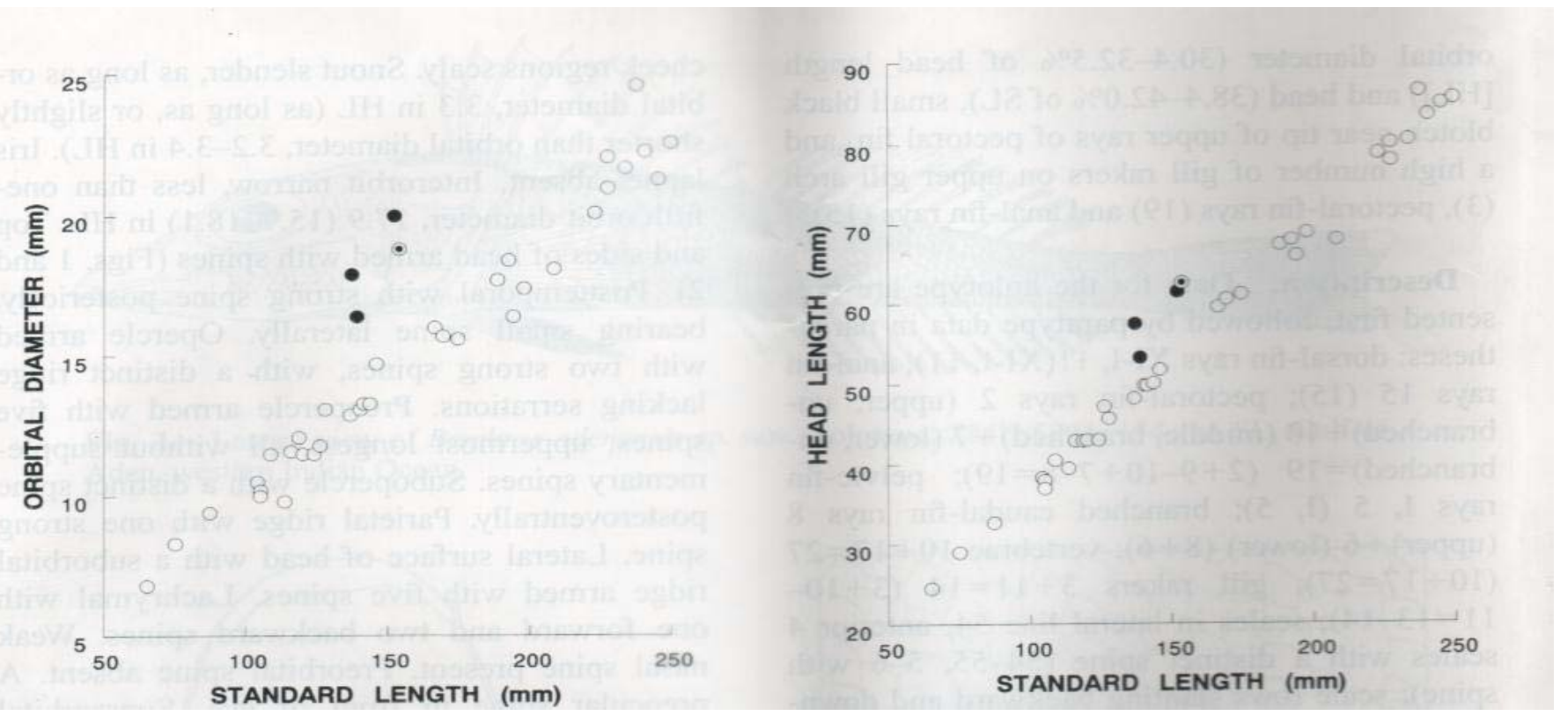

Fig. 4. Relationship between orbital diameters of Bembras adenensis sr.novo (@: holotype; B: paratype) and B.japonica (0).

Fig. 5. Relationship between head lengths of Bem bras adenensis sr. novo and B. japonica. Symbols as in

black blotch near tip of upper rays; and anal- and pelvic-fins pale. The color patterns now are mostly faded. Only a few spots on the dorsal fins, a small black blotch on pectoral-fin and the large black patch on caudal-fin have persisted (Fig. 1).

Distribution. Known only from the Gulf of Aden, the western Indian Ocean, at a depth of $225 \mathrm{~m}$.

Etymology. The name of adenensis is derived from the type locality, the Gulf of Aden.

Remarks. The new species, Bembras ade nensis, can be easily distinguished from $B$. japonica, its only congener, in having larger orbital diameter (as long as, or longer than snout, $30.4-32.5 \%$ of HL in B. adenensis vS. shorter than snout, 24.8-28.7\% in B. japonica) (Fig. 4), pectoral-fin with a small black blotch near tip of upper rays (vs. with several small spots forming irregular bands), 3 gill rakers on upper gill arch (vs. 2), and 19 pectoral-fin rays (vs. 16-18, usually 17,16 in left side of one specimen, and 18 in right side and left side of one specimen). In addition, at comparative sizes, $B$. adenensis has slightly larger head than B. japonica (38.4 42.0\% in SL vS. 32.7-38.7\%) (Fig. 5 ). The number of anal-fin rays was helpful to distinguish $B$. adenensis from B. japonica (15 vS. 13-15, usually 14,13 and 15 in only one specimen each examined in this study), although minor intraspecific variation occurred in B. japonica.

The authors are studying three probable new species of Bembras from southern Indonesia and Australia. They had been reported as B. japonicus by Gloerfelt-Tarp and Kailola (1984), Sains bury et al. (1985) and Paxton et al. (1989). In addition, B. japonica is not distributed in the Gulf of Aden. Therefore, distribution of B. japonica is restricted to the western Pacific, from southern Japan to the South China Sea. A discussion of Bembras laevis Nystrom, 1887, which was placed in the genus Bembradon by Jordan and Richardson (1908), is not included here as that species does not appear to be a bembrid. It is certainly quite distinct from Bembras japonica and, with no spines and ridges on head, lower jaw projecting considerably be- 
yond upper, VI-14 dorsal-fin rays, 23 pectoralfin rays and 40 lateral line scales (Nystrom, 1887), may belong in the percophid Bembrops as pointed out by Nakabo (1993).

Comparative materials. Bembras japonica. 35 specimens: CAS 58562, 2 specimens, 120-124mm SL, South China Sea $\left(20^{\circ} 15^{\prime} \mathrm{N}, 112^{\circ} 30^{\prime} \mathrm{E}\right), 82 \mathrm{~m}, 20$ July 1958, coll. R. L. Bolin; CAS 20774, 2 specimens, 75$105 \mathrm{~mm}$ SL, For-mosa Strait $\left(27^{\circ} 30^{\prime} \mathrm{N}, 121^{\circ} 30^{\prime} \mathrm{E}\right), 80-$ 100m, 17 June 1971, coll. F. B. Steiner; HUMZ 33704, 1 specimen, $197 \mathrm{~mm}$ SL, East China Sea $\left(30^{\circ} 09^{\prime}-31^{\circ} 30^{\prime} \mathrm{N}, 124^{\circ} 13^{\prime}-127^{\circ} 53^{\prime} \mathrm{E}\right), 14$ July 1968 ; HUMZ 35465, 1 specimen, 233 mm SL, fish market, Mimase, Kouchi, Japan, 17 Nov. 1974, coll. K. Matsuura; HUMZ 38991, 39009, 39747 and 39760, 4 specimens, 141-245mm SL, fish market, Mimase, Kouchi, Japan, 2 Mar. 1974, coll. K. Matsuura; HUMZ 41017, 1 specimen, 194 mm SL, fish market, Hamada, Kouchi, Japan, 6 Mar. 1975, coll. M. Toyoshima; HUMZ 47634, 1 specimen, 174mm SL, fish market, Mimase, Kouchi, Japan, 12 Oct. 1972, coll. T. Shimizu; HUMZ 48188, specimen, $105 \mathrm{~mm} \mathrm{SL}$, fish market, Mimase-, Kouchi, Japan, 6 Oct. 1972, coil. T. Shimizu; HUMZ 49406-49408 and 941O, 4 specimens, $146-237 \mathrm{~mm}$ SL, fish market, Mimase, Kouchi, Japan, 15 Nov. 1975, coil. T. Shimizu and T. Kanayama; HUMZ 75359, 1 specimen, $227 \mathrm{~mm}$ SL, fish market, Mimase, Kouchi, Japan, 1 Mar. 1978, coll. E. Yamamoto; HUMZ 79535, I specimen, 192 mm SL, fish market, Mimase, Kouchi, Japan, 1 Dec. 1978, coll. M. Yabe; HUMZ 90521, 1 specimen, $137 \mathrm{~mm}$ SL, East China Sea $\left(31^{\circ} 00^{\prime} \mathrm{N}, 127^{\circ} 28^{\prime} \mathrm{E}\right)$, 122m, 8 Apr. 1981; HUMZ 110622-110623,2 specimens, $87-104 \mathrm{~mm}$ SL, off Saga, Hata, Kouchi, Japan, 3 Aug. 1986, coll. K. Amaoka and K.O; Nato; HUMZ 35778, 35869, 36191, 36742, 36752, 37307, 37327 and 37494, 65-188mm SL, fish market, Mimase, Kouchi, Japan (?), date unknown, coll. K. Amaoka; UMMZ 183212, 3 specimens, 208-249mm SL, Hatta fish market, Toushima Strait, Japan, 13 July 1929, colI. C L. Hubbs and M. Oshima; UMMZ 183211, 1 specimen, $240 \mathrm{~mm}$ SL, East China Sea (at approx. $28^{\circ} \mathrm{N}, 123^{\circ} \mathrm{E}$ ), China, date unknown, coll C. L. Hubbs; USNM 342025, 1 specimen, $126 \mathrm{~mm}$ SL, South China Sea $\left(15^{\circ} 40^{\prime} \mathrm{N}, 109^{\circ} 24^{\prime} \mathrm{E}\right), 110-198 \mathrm{~m}, 27$ Feb. 1960, coll. R. L. Bolin.

Acknowledgments. - We wish to express our sincere thanks to Kunio Amaoka and Kazuhiro Nakaya (HUMZ), and Mamoru Yabe (Laboratory of Physiology, Faculty of Fisheries, Hokkaido University), for providing critical support at various stages through out this study. We are also grateful to T. Iwamoto (CAS), D. Nelson (UMMZ) and H. Wilkens (ZMH) for making materials available to us.

\section{Literature Cited}

Chu, Y. T. and eleven coauthors. 1962. Fishes of the South China Sea. Science Press, Peking. xxxi + 1184 pp. (In Chinese.)

Cuvier, G.L. 1829. Des Bembras (Bembras, nob.), et de l'espece du Japon (Bembras japonicus, nob.). Pages 282-284, pI. 83 in G. L. Cuvier and A. Valenciennes. Historie naturelle des poissons, 4. C. F. G. Levrault, paris-Strasbourg.

Gloerfelt- Tarp, T. and P. 1. Kailola. 1984. Trawled fishes of southern Indonesia and northwestern Australia. The Australian Development Assistance Bureau, the Directorate-General of fisheries, Indonesia and the German Agency for Technical Cooperation, Jakarta. xvi +2 pls. +406 pp.

Hubbs, C. L. and K. F. Lagler. 1958. Fishes of the Great Lakes region. Bull. Cranbrook Inst. Sci., 26: $1-213$.

Jordan, D. S. and R. E. Richardson. 1908. A review of the flatheads, gurnards, and other mail-cheeked fishes of the waters of Japan. Proc. U.S. Natl. Mus., 33: 629-670.

Knapp, L. W. 1979. Fische des Indischen Ozeans. Ergebnisse der ichthyologischen Untersuchungen wahrend der Expedition des Forschungsschiffes 'Meteor' in den Indischen Ozean, Oktober 1964 bis 1965. A. Systematischer Teil, 22. Scorpaeniformes (4). Meteor Forsch.-Ergebnisse (Biol.), 29: 48-54.

Knapp, L. W. 1986. Family No. 155: Platycephalidae. Pages 482--486 in M. M. Smith and P. C. HeemAfrica. stra, eds. Smiths' sea fishes. Macmillan, South

Leviton, A. E., R. H. Gibbs, Jr., E. Heal and C. E. Dawson. 1985. Standards in herpetology- and ichthyology: Part I. Standard symbolic codes for institutional resource collections in herpetology and ichthyology. Copeia, 1985: 802-832.

Matsubara, K. 1955. Fish morphology and hierarchy.

Ishizaki Shoten, Tokyo. xi+v+ 1605+viii pp., 135 pls. (In Japanese.)

Matsubara, K. and A. Ochiai. 1955. A revision of the Japanese fishes of the family Platycephalidae (the flatheads). Mem. ColI. Agr. Kyoto Univ., (68): 1109,3 pls.

Nakabo, T. 1993. Platycephalidae. Pages-535-539, 1299-1300 in T. Nakabo, ed. Fishes of Japan with pictorial keys to the species. Tokai Univ. Press, Tokyo. (In Japanese.)

Nelson, 1. S. 1994. Fishes of the world. 3rd ed. John Wiley and Sons, New York. xvii+600 pp. 
Nystrom, E. 1887. Redogorelse for den Japanska fisksamlingen i Upsala Universitates Zoologiska Mseum. Svenska Vet. Akad. Hundl. Band 13, 4: 1-54.

Ochiai, A. 1984. Bembras japonicus. Page 321 in H. Masuda, K. Amaoka, C. Araga, T. Uyeno and T. Yoshino, eds. The fishes of the Japanese Archipelago. English text. Tokai Univ. Press, Tokyo.

Paxton, 1. R., D. F. Hoese, G. R. Allen and 1. E. Hanley. 1989. Zoological catalogue of Australia. Vol. 7. Pisces. Petromyzonidae to Carangidae. Aus tralian Government Publishing Service, Canberra. xii +664 pp.

Sainsbury, K. 1., P. 1. Kailola and G. G. Leyland. 1985. Continental shelf fishes of northern and north-western Australia. Clouston and Hall and Peter Pownall Fisheries Information Service, Canberra. vii +375 pp.

Shao, K. T. and 1. P. Chen. 1987. Fishes of the family Platycephalidae (Teleostei: Platycephaloidei) of Taiwan with descriptions of two new species. Bull. Inst. Zool. Acad. Sinica, 26: 77-94. 